\title{
The Impact of Capital Market Behaviour on a Nation's Economic Growth: a Case of Nigeria
}

\author{
Ajayi Oziomobo Dada \\ Department of Banking and Finance \\ College of Administration \\ Waziri Umaru Federal Polytechnic PM B 1034 Birnin kebbi, Kebbi State Nigeria
}

\begin{abstract}
The Nigerian capital market behaviour in relation to its economic development efforts is hamstrung by factors like information asymmetric, regulation overbearing, inconsistency and insider trading which had been the hindering factors in the development of the market. Suffice to say that capital market is an economic barometer usually use to detect the economic pulse of any nation in their quest to toe the line of thresh hold in the comity of nations; which spurred my interest in the behaviour of capital market as it relate to its nation's economic growth and development function with the key area of human behaviour that is constantly hindering the market development in consonance with behavioral finance as it plays complementary role with long held efficient market hypothesis. Though, the impact of the stock market on the Nigeria economic growth rate is found to be insignificant due to structural rigidities that characterized the economic policies. The market plays a key role in helping to accelerate the Nigerian economic growth and development. Therefore recommend that the adoption of strategic management principles and appropriate enabling rules and regulations should be applied to minimize regulatory inconsistency and policy somersault with negative consequences.
\end{abstract}

Key words: Asymmetric information, Capital market, Behavioural finance, efficient market hypothesis, and economic growth.

\section{The introduction}

The imperatives of capital market in fostering economic activities cannot be over emphasized. It helps in optimal mobilization of savings and allocating funds to a specific long term gestation projects where funds will ordinarily not be available. Oke and Adeusi (2012) contend that capital market impact strongly on the Nigerian's economic growth and development and that the exchange is still operating under a semi strong category due to the prevalent of asymmetric information and overbearing regulation, but its catalytic role in the provision of long term funds had immensely helped in the Nigeria's economic growth and development. Solomon (2009) and Emmanuel (2010), observe that there is a positive correlation of financial market and economic growth, and capital market accelerate economic growth in real sector. It equally facilitates and helps in diversifying firms' opportunity to external finance, though relying on financial reporting and assurance (Kolapo and Aderamola (2012)); and regulatory platform on which the capital market on which it thrived.

The crux of the Nigerian's capital market rest on the Nigerian stock exchange, it came into being in 1960 and began operation in 1961. It was then known as Lagos stock exchange and in 1997 renamed the Nigerian stock exchange with branches in the major commercial cities of the country. It began operations with 19 listed securities on the exchange in 1961 and at present (2011) has over 262 securities listed on the exchange. Tokumbo (2011) and (Solomon, 2007), the incorporation of the central security clearing system in 1992 and liberalization policy adopted in the wake of 1995 had led to the removal of the restrictive laws that constrained foreign investors in the market. The capital market can be view as essential platform for accelerating economic growth and its functions rest squarely on favourable economic and political environment with correspondent institutional support to build confidence in the future and the confidence of investors in the future form the bed rock on which capital market is build upon.

There is no doubt that the exchange had played a pivotal role in the Nigerian's quest to accelerate her economic development, the World Bank (2007); and Olatundun \& Ademola (2008), observed that financial market in Sub-Saharan are imperfect as a result of prevalent of inconsistence financial regulation and the seeming lack of market liberalization due to agency problems between public and private sector, equity share holders and creditors, managers and capital contributors among other similar issues. Thus, the market behaviour is shaped largely by persistence information asymmetric and agency problems which create a wedge between the costs of internal and external fund.

Suffice to say that capital market is an economic barometer usually use to detect the economic pulse of any nation in their quest to toe the line of thresh hold in the comity of nations; which spurred my interest in the behaviour of capital market as it relate to the Nigerian's economic growth functions with an area of human 
behaviour which is constantly hindering the Nigerian's capital market development in consonance with behavioral finance as it plays complementary role with long held efficient market hypothesis.

\section{The essential objectives of economic growth and development}

The quest for an improved sustainable national economic growth and development is geared toward achieving the following economic objectives, which is centered on meeting the fundamental needs of individuals and society in general. According to Atoyebi (2013) increase in economic growth rate will lead to the capacity of a nation to produce goods and services to meet the demand of its developmental needs over a period of time. Therefore economic growth entails the process by a nation's wealth is capable of increases progressively over time period. In determining a nation's total output of goods/services as viewed in term of its gross domestic output (GDP) as a measure of its economics' progress. It can also be measure as aggregate income or relative increase of per capita GDP. Essentially, productivity connotes producing more goods and services efficiently and effectively employing the same input of capital, labour material and energy. The essential indicator of economic progress of any nation entails the followings.

\section{- $\quad$ Improved quality of life}

It entails the ability of the development to usher in an improved quality of life through the provision of shelter, effective health care delivery, security of life and property and availability of affordable food. It should be plan to be affordable and available as basic necessities of life.

\section{- $\quad$ Self-esteem}

National development should imbued in individual a lofty sense of self-worth and respects, dignity, which should culminated in individual upholding the highest societal values and personal sense of fulfillments. It should entrench the need for recognition, respect among others through the provision of employment opportunities and good governance.

\section{- $\quad$ Freedom from Servitude}

According to Joseph (1997) national development should aim at freeing individual from servitude of man to nature and other men, misery and dogmatic institutional beliefs so as to unfetter unwarranted constraints to individual and society socio economic development. It should usher in scientific and conscious ways of reasoning.

However, for the national development to achieve its core objectives, in the context of socio economic well being of its citizen and the society at large, Adelaja (2007), the development plan should be flexible and well articulated. It must be inherently be capable of high sustainability and flexibility as some of the priority areas of yester years may no longer be tenable and other opportunities may arise in the current dispensation as a result of changes in time and events. Therefore, the contribution of the core stimulant, capital market for national development need be examined continuously. (Michael, 2010).

\section{The role of finance on economic growth and development}

Dimitris and Eftymios (2003) observed that there no agreed stand point that financial development is crucial to economic growth among the economist. Pagano (2003) conclude by using AK model constant economic growth rate directly depend on the portion of saving channel to investment. Thus, opine that conversion of savings into investment lead to financial deepening necessary for funding economic activates. It was revealed using a theoretical model that banks acting in collusion within a stable equilibrium, their ability to affect growth positively depend on the number of banks and the degree of competiveness of the entire financial system. Also educational development is of paramount importance to economic growth, as pre condition, financial and educational underdevelopment stand as an obstacle to any meaningful growth envisage in the economy. However, Greenwood and Jovanovich (1990) use a model that permits the examination between economic growth and income distribution and on the other hand between financial structure and economic development.

The onus of positive effect of financial structure on growth lies on the efficient investment undertaking and capital allocation since the agents possess better information pertaining to the type of stocks either on aggregate or idiosyncrasy about a particular project as view by classical as regards to growth and financial development. According to the Levi (1991) using endogenous growth model to evaluate stock market contends that it accelerate growth because ownership of firm can easily be traded without causing ripple in the process of production and financial agents are allow to diversify their portfolios as they deemed fit. The model does imply that in the absence of stock market the agent may not be willing to invest due to the tendency to avoid risk. Hence, the market accelerate growth by averting premature capital liquidation that which tend to enhance firm liquidity position, thus reduce liquidity risk thereby encourages firms' investment.

However, Singh (1997) observe that financial development may not aid growth for obvious reason that in developing countries plague with volatility and arbitrariness of stock pricing system potent it as unreliable guide 
to efficient investment allocation. Also the link between the stock and currency market in time of economic crisis may course instability in the macroeconomic and impede long run economic growth and market may downplay the prevailing group banking system in the developing economies like Nigeria

.However, (Joseph, 2000) affirms that the consequences of recent global financial crisis and high costs that were paid by the developing countries draw attention for need to redesign the global economy architecture. It becomes glaring that more attention should be focus on the future recurrence through the modification of the global economy for such crisis to be less frequent, deep and also in length. Much attention should be directed in improving transparency, though the much needed information in high leverage economies like South Korea and highly cyclical chip industries are readily available. Equally worth of note is that the last economic crisis also happens in World's most transparent countries like Sweden, Norway and Finland which shows that transparency alone cannot immune a country from crisis as deeper analysis has shown that transparency alone is not the only core issue because these countries have relatively maintain three decades of steady economic growth and enjoy consistence increase in transparency ranking.

Countries like China, India among others that are less transparent came out of the crisis unscarred, it therefore shows that while improve information i.e. transparency may lead to optimal allocation of resources, but combine theoretical and empirical analysis cast doubt in its role of enhancing stability in an economy. Hence, transparency euphoria agenda was drastically eroded as meaningful transparent agenda need be comprehensive, including the offshore banking, hedge funds and the action of the central bankers. Stglitz (1999) observed that the second major attention of reform should rather be focus on the strengthen of financial institutions as the difficulties experience by the advance countries in establishing a strong financial institution give credence that guiding against adverse economic crisis pose long term challenge to developing economies. Other viable reforms include collective action clauses in bond, improve corporate governance and systematic bankruptcy provisions were also suggested, though receive stiff opposition as a matter concerning systematic bankruptcy provisions were consider to be so technical to gain wide general acceptance. It is also perceive in some quarters that the issues of good corporate governance seem cogent but their role may be blown out of proportion in time of economic crises. The major area of convergence agreement for change is in the short term capital flows as the attendant risks are more than the benefits in an instance where countries that now engage fully in economic liberalization may return to more restrictive measure than was obtained before the economic crisis. With the growing body of theoretical evidence and experiences in term of full capital liberalization and stability, one may pulse to think that there may exist fundamental problems that plaque the international economic design beyond those discuss above, specifically to the issues of representativeness and accountability.

At this juncture there is need to ask whether those decision makers put the interests of the millions of people throughout the World into consideration instead of paying much attention on financial market rather than the core issues that affect the lives of people, businesses, workers' welfare and wider view of economy predicaments and these are some of the unanswered questions sequel to the economic crisis in which the world is emerging. Ii is pertinent to note that financial market deals with the creation of financial assets and liabilities, in consonance with state preference model; it is a systematic model of handling uncertainty about the future which has a list of events called state of nature as its function. Each asset is defined over all possible states of nature. Thus, when investors buy assets, they are purchasing a list of state contingent claims that enumerate payoffs to be made when the state of nature is revealed. In concomitant with this model, Financial market can be seen a platform were the intermediaries obtain short and long term funds from ultimate lenders and lend them to the ultimate borrowers. The two markets are money and capital market.

\section{The money market}

The market is a system where short term financial resources are bought and sold with one or less than a year transaction period. The participants include private individuals, business firms and government agencies; enable them to finance consumer credit and deficit financing facilities to government. The market platform consists of an integrated network of dealers like banks and other participants link by electronic network system via telephone, E-mail, fax. Telex among others. Activities of money market were largely driven by the implementation of monetary and fiscal policy tools for liquidity management which is complemented with the utilization of the central bank standing facility (deposit and liquidity) facilities and cash reserve requirements. In Nigeria, government remains the dominant player with its securities constituting $68.0 \%$ per cent of money market assets outstanding at the end of December 2008, while private sector issued securities accounted for $32.0 \%$. 


\section{- Instruments of money market}

\section{Call money}

This provides the means whereby money is lent on day to day basis, often referred to as inter-bank borrowing instrument. In Nigeria, the activities at the interbank funds market increased in 2008 in value term to \#20.403.6 billion.

\section{Nigerian Treasury bill}

These are instruments for short term borrowing issue by central bank on behalf of the federal government to meet its short term treasury need with a maturity of 91 days sold in discount basis. NTB worth \#916.3 billion were issued in 2008, the breakdown of the allotment showed that banks had $41.9 \%$, mandate and internal fund customers $46.9 \%$, Discount houses $7.5 \%$ and brokers $0.4 \%$.

\section{Treasury certificates}

They are medium term government securities that mature between one and two years. It is designed to bridge the gap between the short and long term federal government loan requirements.

\section{Commercial papers}

These consist of promissory notes of blue chip companies which are sold to mobilize funds usually for three months at lower rates. When company feels that it is not worth paying intermediaries, especially the credit worthy companies may look beyond banking system by going on their own, to issue short term unsecured notes call commercial paper with a maximum maturity period of 90 days. Thus, enable them to borrow at a discount rate of 1 or $1 \frac{1}{2} \%$ below the prime lending rate that may be charge by banks. Investment in commercial papers is supplementary to bank credit to the private sector and constituted $29.3 \%$ of the total value of money market assets outstanding in 2008 .

\section{Certificate of deposit}

It evidence indebtedness of money deposit banks to a holder which mature between three months to one year. Though the contract can be broken if the need for fund arises before the maturity date and bank usually accept this, it usually attract penalty in form of reduce rate of interest payable and may attract other charges for breach of contract. If you need the money before the maturity, bank will usually allowed you to withdraw it but it will attract a penalty in form of a reduced rate of interest.

\section{Bankers' acceptance}

They are issued inform of draft accepted by banks used in financing foreign and domestic trade. It has a maturity period of less than 60 days traded in an over the counter market. Since the banks accept liabilities in case of non repayment default, they are highly negotiable instruments. Bankers' acceptance accounted for $2.4 \%$ of total value of money market asset outstanding in 2008 .

\section{Repurchase agreements}

It denote the sale of short term securities by usually by government dealers to investors whereby the dealer agree to repurchase it back at an agreed future time designed to meet the need of the investor. It has a few days maturity period

\section{- $\quad$ The money market institutions}

The various money market institutions in money market are the central bank, Nigeria deposit Insurance Corporation, commercial banks, discount houses, microfinance institutions, and other specialized banks.

\section{The capital market}

The central theme of the research is focus on the capital market in relation to its pivotal function to accelerate economic growth. It is the segment of financial market where long term financial assets are traded. Its instruments mature above one year to perpetuity. The market is categorized as:

\section{Primary market}

It deals in rising of new financial claims. The market is also called the new issue market.

\section{Secondary market}

The secondary market deals in the second hand shares, that is the buying and selling in the existing shares and stocks. Atoyebi (2012) contends that the spillover effects of the recent global economic crisis and its attendant consequences on the Nigerian capital market call for the adoption of strategic management to contain and curtail the negative consequences that normally precedes the crisis. This he opines will entrench efficiency 
in the market, effective and consistent regulation, and stable macroeconomic growth. The capital market plays a key role in the economy due to its ability to provides the companies a veritable sources of capital and investor an opportunity of company ownership status with its accrue gains base on the performances of the company in term of capital gain and dividend growth. Accordingly Okafor (1983) distinguish the market into three folds namely securities exchange like equity, and bond market; organization of the market like the over the counter and security exchange market, and primary and secondary market respectively. For clarification, bond market can be further subdivided into corporate, government and municipal bond.

As afore mentioned the market is generally categorize into primary and secondary sections. The primary section trade in new issues offers with subsequent trading in the secondary market and the secondary market where the old stocks are being traded. Generally, the instruments of capital market includes among others, government development stocks, bonds, industrial loans, preference shares and equities. Moreover, Augustine and Nwanneka (2012) viewed capital market as unique in a financial system as result of its key role in an economy and moreover Levine (1991) classifies these roles in term of capital mobilization for businesses, mobilization of savings for investment, redistribution of wealth, enhancing company's growth prospective, creating of investment opportunity for small investors, avenue for raising capital by government for developmental projects, promoting corporate governance among others and most importantly being use as a barometer for testing the economic wellbeing of a nation.

Being the main sources of long term finance, the capital market is sine qua non to any nation' economic development agenda; specifically it facilitate economic growth and through the mobilization of savings from various surplus units and allocate it through a competitive pricing mechanism to the deficit units of the various economic sectors. The essential instruments of the market are mainly the followings.

\section{Equity}

Equity holders are the inventors who subscribe for the common shares/stock of a company. Equity instruments are variously known as common stocks, ordinary stock, shares etc. returns to an equity share holders depend on the dividend declared and the appreciation on the value of their shareholdings.

\section{Debt instruments}

Debt securities are creditorship instruments which attract fixed returns to the holders. They include; government loan stocks (bonds), preference shares, and corporate bond, debenture and term loans. Debt instruments can be issue at premium, par, or discount with the return of fixed income written on the face of the instruments.

\section{- $\quad$ The capital market institutions:}

The capital market institutions are the issuing houses, stock brokerage firms, discount houses, share registrars, unit trust, central bank, securities and exchange commission, stock exchange etc.

\subsection{The functions of capital market}

- $\quad$ Capital formation: It facilitates capital formation in an economy by providing an avenue where sellers and buyers of short, medium, and long term funds meet.

- Macroeconomic stability: The market serve as a veritable tool for efficient and effective implementation of the government policies designed to steered economy in the desired direction.

- $\quad$ Serve as an agent of economic linkage: It help to mobilize financial resources from one sector of an economy to other sectors thereby enhancing the optimum utilization of available financial resource in an economy.

- $\quad$ It accelerate economic development: Financial market serves as an avenue for channeling domestic and foreign capital tailored toward the development of a crucial infrastructure needed to ginger economic activities.

- The capital market helps in deepening liquidity in an economy which facilitates payment and settlement processes (Glenn, 2009)

\subsection{The Nigerian stock exchange}

The exchange was established in 1960, and then known as the Lagos stack exchange and formally commences business in 1961.In consonance with the indigenization policy of 1977 it was renamed Nigerian stock exchange with branches and trading floors in the major commercial cities. Its former business commences in Lagos in 1961, follow by Kaduna, Portharcourt, and Kano in 1978, 1980, 1989 respectively; Onitsha and Ibadan in 1990, Abuja and Yola 2002 among other newly established trading floors across the country. The exchange which started operations in 1961 with the 19 listed securities now (2011) has over 202 securities listed on the exchange. Ishola (2008) view the main thrust of the market in term of optimal transfer of relatively scarce long term financial resources from the surplus units to the deficit units efficiently and these units are said to be 
better off if it facilitates efficient transfer of funds. The borrowing and lending rate are used by producers who will accept when the rate of return on the least profitable project is just equal to the opportunity cost of external fund i.e. the borrowing and lending rate. In practice, as obtain in the Fisher separation theorem, scarce savings are optimally allocated to productive sector in a fashion that benefits everyone. Thus, in an efficient market all participants are price takers since the assumption of information efficiency implies that cost is negligible and are transmitted and received simultaneously by individuals. The market can also be said to be efficient if the intermediaries (agents) who channel funds from the ultimate savers to the end users can do so with minimum cost that provide a fair returns for their services. The internationalization of the capital market by government through the abrogation of laws that constrained foreign participant and the subsequent repeal of the exchange control Acts of 1962, Nigerian enterprise promotion decree of 1989 now pave ways for the foreigners to participate in the market as operators, investors and there is no ceiling to the percentage of foreign holdings in any registered company in Nigeria.

Therefore, the current status of the listed companies connotes foreign and multinational affiliation, representing a cross section of the economy ranging from agriculture, manufacturing to service industries. The Nigerian stock exchange for over 39 years of operation is devoid of any substantial fraud scandal and insider dealings. Moreover, in 1985 a set of requirements for enlistment were issued to allow smaller and medium enterprises registered as second tier securities. Thus, bring about two types of securities market in NSE known as First tier and second tier markets.

\section{- $\quad$ The first tier market.}

The first tier or main market constitute the well established companies that have the ability to meet the stringent requirements such as being a public limited registered company as stipulated by companies and allied matter Acts of 1990; submit to exchange five years financial statements and business records; last audited account should not exceed nine months; can raise unlimited amount if the director/company's power permit it; annual quotation fees would be base on the its market capitalization; at least $25 \%$ of its nominal value of its share capital must be offer to the public. The number of its share holders must not be less than three hundred; must submit to the commission quarterly, half yearly and annual accounts after listing; its securities must be fully paid up at the time of allotment; un allotted securities must be sold on NSE trading floors, and there are provisions for merger, acquisitions, unit trusts and mutual funds.

\section{- $\quad$ Second tier market (SSM):}

The second tier market is design to accommodate the less strong companies especially the indigenous firms who could not meet up with the requirements of the first tier market to enable them have access to the stock market. The requirement entails being registered as a public limited company under provisions of the companies and allied matters Acts. of 1990; submit to the exchange financial statements/business records for the past three years, though fresh companies may be considered; the date of the last audited accounts must not exceed nine months; the amount of money that can be raise may not exceed \#20 million; annual quotation fees is \#30,000 flat; at least $10 \%$ of the nominal value of the share capital must be offer to the public; the number of the share holders must not be less than 100; the company must submit half yearly and annual accounts after listing; securities must be fully paid up at the time of allotment; un allotted securities must be sold on the NSE trading floors; and there are no provisions for merger, acquisitions, unit trusts and mutual funds.

\section{Unit Trust}

A unit trust is a method of investment whereby monies of individuals are pooled together in a fund, the investment and management of which are subject to the provision of the trust deed which established it. Unit trust is regarded as traditional mode of indirect investment with its advantages of spreading of risk and expert management especially in security and property management.

In the Nigeria context, unit trust scheme is under the regulatory frame work of the Securities and Exchange Commission who make sure that the enabling provisions of companies and allied matters Acts. 1990 and investment and security Acts 2007 as amended are complied with accordingly both in operations and the establishment of the scheme. Sections 575 to 589 of CAMA provide among others that:

No person shall established or operate a unit scheme unless such scheme is authorized and registered by the SEC;

A formal application for authorization must be made by the manager in a prescribe form accompanied by such documents as may specified to the SEC, and

The SEC may authorize and register the scheme if the following conditions are met:

The manager and trustee's competence and integrity are satisfactory;

The manager is a body corporate and having a minimum paid up capital of \#250,000;

The trustee under the scheme is also a body corporate licensed under the relevant statue; 
The manager being a body corporate satisfies the SEC that the affairs of the scheme shall be handled independently from its own affairs,

The trust deed is in accordance with the provisions of the CAMA 1990 and all rules that may be prescribed from time to time and a copy is deposited with the SEC, and

The name of the scheme is not undesirable.

\section{- $\quad$ Parties to unit trust}

\section{The managers}

These are the promoters who are usually a firm of stock brokers, investment bankers etc. Who appeal to the public to entrust their monies on them. They formulate the investment policy of the trust fund, the physical investment of the funds, distribution of income and dividends to various unit holders. They derived their income from $5 \%$ of the total value of new units issued and annual management charges of $1 \%$ on the total income of the unit trust.

\section{The Trustees}

These are group of person or institution which may be a banker or insurance company appointed under the trust deed to supervise the activities of the managers and look after the interest of the unit holders. Legally they are the owners of the trust funds. They also ensure that trust deed are complied with, issuing certificates, creation and liquidation of unit; while ensuring that price of units are correct and registration of units and unit holder.

\section{The beneficiaries}

These are the investors who have become unit holder by virtue of their contribution to unit trust.

\section{- Types of unit trust}

- Income funds:

These are unit trusts that invest their funds to earn maximum income only. The underlying securities are money market instruments and fix interest securities. This type of unit trust is adjudged suitable for those whose investment objective is to have above average and rising income.

\section{- Capital growth Funds}

The emphasis here is capital growth through the increasing performance and prices of the underlying securities; in other word the securities of the trust would be security of companies with high capitalization earnings. The unit trust with capital growth motive is suitable for high tax payers.

\section{- Balanced or General funds}

These combined the motives of income funds and capital growth funds. Investments are made in blue chips (shares of leading companies) where there is both income and capital appreciation potentials. Investors whose motive is long term growth of income and capital would find this type of unit trust suitable.

\section{- $\quad$ Specialized Funds}

These are unit trusts that engage in investing their funds in particular industries or certain sectors of the economy and they are usually preferred by investor wising to diversify.

\section{- Oversea Funds}

These are unit trust that channeled their funds to investment in shares of companies outside their countries; it is design to cater for small investors whose objective is to diversify risks.

\section{The central securities and clearing system}

The CSCS limited is a subsidiary of the stock exchange establish in conformity with the international standard requirement in 1992 with the responsibilities of serving as a sole depository for all the shares traded at the stock exchange. Moreover, it undertake the responsibilities of settlement, clearing and delivery of all transactions on the exchange electronically, thereby enhancing the efficiency of the exchange and making it more customer friendly. Its specific benefits to the various stake holders include:

\section{The benefits to investors}

-The stocks in CSCS system can be used as collateral for loan facilities after the transaction cycle of $\mathrm{T}+3$ settlement cycle, i.e. 4 days after transaction.

- The investor's statements of stock position are issued monthly through the stock brokerage firms or on demand for \#100 fees. 
- Investor can now take the advantages of CSCS and speculate taking the advantages of capital appreciation in their investment because of $1+3$ settlement cycle.

- It reduces risk associated with loss of certificate.

- Stock transactions are transparent and can be easily traced.

- It offers ease of reconciliation of stock holding

\section{- $\quad$ The benefits to the quoted companies}

- $\quad$ It reduces the cost associated with production of certificate any time shares exchange hand to the barest minimum.

- $\quad$ A single transaction may involve issuance of many certificates, depending on the allotment made. This no longer tenable as only few shareholders ever request for certificate.

- $\quad$ Out of 900.000 shareholders that uses CSCS 1td, only about 8,000 shareholders have requested for certificate so far as at the end of 2005.

- Amalgamation of several accounts for shareholder on the register lead to reduction of associated cost to the company.

- $\quad$ It enhances the much needed dynamism in the security market.

- The stock brokerage firm

- $\quad$ It enhances prompt inter member money and stock settlement process.

- The onerous tasks of share delivery are minimized.

\subsection{The members of the Nigeria stock exchange:}

As a matter of design, the constituents of the NSE's council members are the president, first vice president; second vice president, the past president, director general and other important dignitaries like the Lagos/Ibadan chairman, individual members and four dealing members The National council members include the president, first vice president, second vice president, the past president, director general/CEO, Lagos/Ibadan chairman, individual members and the four dealing members. On the whole the market has network of exchange firms, law firms, issuing houses qualify audit firms and reporting accountants among others.

\section{- $\quad$ Dealing members}

The NSE's dealing members unlike the London and New York exchange system where there exist two different dealing members known as:

The jobbers

They serves only in the capacity of principal; buying and selling shares on their own accounts and dealing only with the brokers or other jobbers.

\section{- $\quad$ The brokers}

The brokers on the other hand acts as an agent for the customers. In Nigeria there is only one class of dealer call the stock broker who combine the functions of both jobber and the broker. He can buy or sell from one another either on his own account or for their clients.

Therefore a dealing broker quotes two prices i.e. $140-145 \mathrm{k}$, he is prepare to buy at the lower price and sell at the higher and the differences known as the dealer's turn, for example $5 \mathrm{k}$ in the example above is his return.

As obtained in Nigeria, London and New York the procedure follow the same pattern, the customer gives an order to a brokerage firm who then relay it to the floor for execution. The receiving broker goes to the area where the security is traded and seeks to narrow the spread between the bids and when convinced that he had obtained the best possible price, he will then complete the bargain. However, in Paris, Brussels, Zurich etc. the trading procedure may employ auction system where prices are establish through bids and offers made on specific security at a particular period of time. The NSE publishes on the printed, broadcast media, their web site and stock market page of the Reuters electronic contributor system (NSX-A-B) showing the particulars of various securities, business done, dividend, interest rate, price at which the transaction on a given security was conducted among others.

\subsection{The stock exchange all-share- index}

Since January 1984 the Nigerian stock exchange published a stock exchange index. The index is an aggregate of the market capitalization of all the industrial equities listed at the market as follows:

$\underline{\text { Current market value }(\mathrm{CMB}) \times \underline{100}}$

Base market value (BMV) 


\section{$=\mathrm{CMB} \times 100$ \\ $\mathrm{BMV} 1$ Using 1984 as the base year.}

Though where exchanges other than prices variation occur which affect the index, an adjustment is made to eradicate the effect of such changes. These changes may include new listing, delisting and increase in the issued capital of listed companies.

\subsection{The functions of the stock exchange:}

Augustine and Nwanneneka (2012) opine that the adverse effects of last global economic crisis serves as a warning signal that the Nigerian Capital market should adoption strategic management to facilitate efficiency, effective regulation and stable micro economic environment. However, the market provides investment outlets to the general public and institutions who buys securities in the following ways.

- It grants dealing membership of the exchange to persons and institutions.

- Making rules and regulations concerning the stock exchange

- Publishing all the official lists of the exchange

- Adjudicating offences of dealing members.

- It provides opportunities for attracting foreign capital for Nigeria's economic development.

- It facilitate dealings in government and corporate securities

- It protects the public from shady dealings and practices in quoted securities.

- It provides the benefits of raising new capital limited only by the company's borrowing capacity.

These problems, which impinge on the efficiency and performance of the securities markets, are indeed real for the Nigerian securities market. Studies of the market by Fidelis and Davidson (1997) conclude that the market is thin and narrow, while Gill (1982) notes the absence of large volumes of transactions. The paucity of shares to trade in the market was attributed to the "buy-and-hold" attitude of Nigerian investors (Phillips, 1985). It has also been pointed out that the investing public is largely unaware of the opportunity for investing in the securities markets. Generally, the mobilization of domestic Savings through the securities market in developing countries is seen as typically inefficient (Adam et al., 990). The factors that contribute to this include discriminatory tax policies on different financial assets, direct credit allocation policies and interest rate controls. The presence of distortions in the process of developing securities markets calls for new regulatory mechanisms. The Securities and Exchange Commission (SEC) in Nigeria, regulatory institution put in place to supervise and regulate the activities of the players in the securities market to ensure its healthy development.

The market provides various avenues for listed firms to sources funds far and above its internal financing capability. Such funds are usually meant for business expansion or to curtail the effect of inflation as to continue as a going concern. Sunday et al (2009) also observe that the indigenous companies that were listed on the first and second tire segments of the market now enjoy the patronage of the international investors, thereby facilitating the much needed inflow of foreign direct investments into the country. This gives credence to say that the enlistment of the indigenous companies into the capital market thus confer prestige and favourable reputation on the products and their credit ratings by the public and the stakeholders.

Bayero (1996) equally opine that the free entry and exist offer by the stock market create an atmosphere of flexibility in transferring of ownership as it is much cumbersome to do so in a privately own company without creating chaos in the capital structure of the company with its great attendant consequences on the smooth operations of the company. However, in publicly quoted company, as long as the stock broker can find a suitable buyer or seller for his clients, the transfer of such shares i.e. ownership within the confine of the rules and regulations governing such transaction do not normally affect the operations of the company. Other notable functions of the capital market are the opportunities to acquire suitable technologies and expertise as a result of the international connection their listing avail to them. More so, the enormous benefits accruing to them from the implementation of the Nigeria enterprise promotion Acts and the privatization policies are capable of strengthen and accelerating the economic growth and development of the country. Though, with these laudable advantages of the capital market, it is disheartening that the market is still bedeviled by bureaucratic system of the Securities and Exchange Commission and other undesirable activities that is hindering the smooth operations of the market. The private sector were subjected to leaps and bounds through excessive fee charge and inordinate rules and regulation that constraints smooth operations of the market thereby resulting to participants looking for easy way out through cutting of corners and engaging in shady deals. If it is a fact that the engine of economic growth and development in Nigeria partly rest on this sector which is endow with capacity to create jobs for the teaming population, it become obvious that that charges should be moderated and effective regulative banner put in place also the fees demanded by stock brokers, registrars and issuing houses should be curtail and within the reach of the clients as their charges are on the increase and their efficiency 
dwindling. The imposition of all sorts of taxes by various tiers of government should be look into to check excessive and unnecessary cost burden of doing business by the indigenous listed companies in Nigeria.

According to Chuke (2012) the recent financial crisis with its consequences led to the Nigerian capital market meltdown recently, provide an opportunities for both foreign and local investors to buy shares at much lower prices that is capable of rejuvenation since the market strongly portrays a better future prospects. There appear to be no better opportunity than now to buy shares in the market since the market still commands high earning per share, dividend yields and good bonus and low price earnings ratio. With the current fully internationalization of the Nigerian capital market and the planned demutualization of the exchange give room for foreign investors to totally own a Nigerian registered company and exercise full control. The current melt down of the Nigerian Capital market potent an opportunities for massive investment and reap the enormous accrue future benefits.

\section{Efficient capital market hypothesis (EMP)}

This prominent theoretical position evolved in the mid 60s from the $\mathrm{PhD}$ dissertation of Eugene Fama. she actively posited that active market include all well inform and intelligent investors and therefore securities are appropriately priced and it reflect all available information concerning the underlying security. Philip and Paniscos (2001) also put forward that if market is efficient, no information or analysis can be expected to result in the out performance of an appropriate bench mark both on technical and fundamental analysis. The EMH posits that investors adjust securities prices rapidly to reflect the effect of new information. (Maku \& Atanda, 2009; and Mayowa \& Richard, 2012) observe that proponent of efficient market hypothesis argue that stock prices are essentially random and therefore chances of profiting from speculations is non existence. The market is base on the assumptions that share price follows a random work and successive price change is independent of each other. This implies that no individual can make abnormal profit from trading in securities since share prices are not mispriced in any form of symmetric or predictable way. Also Samuel and Wilkes (1981) define an efficient market as the one in which prices of traded securities always fully reflect all publicly available information concerning those securities and that the necessary condition for an efficient market includes accurate signals for investor's choices and shows that today's price reflects all publicly available information which is the best estimate of tomorrow's price. To this end, the efficient market is one in which security prices adjust rapidly to the infusion of new information and current stock prices fully reflect all available information, including attended risks involve. Hence, stock market is said to be efficient if information is widely and cheaply available to investors in such a way that share prices are fair, that is the price reflects all available relevant and ascertainable information in the market which result from the presence of numerous, rational profit maximizing investors who are actively competing with one another. More so, Malkiel (2003) equally contends that irrespective of the kind of analysis, no analyst can make abnormal profit; therefore market prices will reflect the best estimates for the risk and expected returns from the assets base on all the information available as at the time of references. Thus, the information reflected by the current market prices include information appertaining to the company offering the share and the general market information follow a random order in their occurrence. The interesting feature of random walk hypothesis is the persistence of random shocks. Early empirical tests of the random walk hypothesis by Fama (1965) show significant departure from randomness and were inconclusive and insufficient.

Also Maku and Atanda (2009) opine that the major thrust of the random walk hypothesis is the current prices of stock fully reflect all the information that is contained in the historical sequences of prices. Therefore forecasting future stock prices through the examination of the historical past record of prices will not yield any benefits to the investors. Suffice to say that if random walk is true, then it is direct repudiation of the technical analysis as Fisher and Jordan (2005) observe that there is need to study past price changes as no value in technical analysis. Moreover, Jensen (1978) defines the efficient market as one where there is a zero competitive equilibrium condition and it is impossible to make economic profit i.e. risk adjusted net of all cost by trading on the available set of information present in time $t$. Since the information present at time $t$ is all the information presently reflected in the current stock prices. The implication is that stock price at time $t$ is as a result of all the available information $t$ and stock price in time $t+1$ because when information infiltrate into the market it spread quickly and it is incorporated into the stock price immediately. On his analysis, Malkiel (2009) observe that the present stock price cannot accurately be use to predict the future stock price. The implications of efficient market hypothesis are profound, individuals who sell or buy securities do so under the assumption that the securities they are buying are worth less than the selling price they are paying, while the one they are selling worth less than the selling price. But on the notion that the markets are efficient and the current price fully reflect all information, then buying and selling securities in an attempt to outperform the market will effectively been a game of chance rather than skill. In view of the above EMH holds that the future price of a security, given today's set of information is equal to today's price compounded at some desired return that is commensurate with the risk associated with the security. 
Basically, the three types of efficient market hypothesis are known as weak, semi strong and strong form. One might be more inform about the distinctions and variations as underlying on the continuum with random walk model.

\subsection{Strong form of efficient market hypothesis.}

The strong form of efficient market hypothesis held that market is efficient if all information relevant to the value of share are generally available or not exist or potential investor can quickly and accurately reflect on the market price. It is a satisfying and appealing form of EMH in a theoretical sense. But it fail to address the draw back in practice for its difficulties to confirm empirically as it would be unlikely to win cooperation of the large section of the financial community insider dealers. The assumptions hold that in the strong form efficiency the following obtains. That share prices reflects all information and no one can earn excess returns; the market exist where investors cannot consistently earn excess returns over a long period of time and the issues of insider trading is introduce where an investor trade on information not yet publicly available.

\section{- $\quad$ The strong market form's impossibility}

The existence of fund managers who continuously beat the market implies that there are no formof efficiency also normal practices and empirical evidences suggest that stock markets are unlikely to be strong form.

\subsection{The semi strong form of market hypothesis}

This connote the less rigorous form of market efficiency as held by EMH which posits that market if efficient if all relevant publicly available information is quickly reflected in the market price. However, the semi strong form however appeals to common sense. It states that no investor can earn excess returns from trading rules base on publicly available information. The test of this market form have shown that no investor can earn above normal return on publicly available information such as annual accounting reports, block trade , (Rol, 1978) such as earnings announcements, stock split announcements, dividend and repurchase announcements. Thus imply that if individual buys the stock on the announcement date and still does not make above normal return. It assumptions are: Share prices adjust instantaneously and in an unbiased form to the publicly available new information so that no excess returns can be earned by trading on that information; the efficiency implies that fundamental analysis will not be able to produce excess returns; and for its test, the adjustments to previously known news must be of a reasonable size and must be instantaneous and that, if there is consistent upward or downward adjustments it would then suggest that inventors had interpreted the information in a bias and in efficient way.

\subsection{The weak form of EMH}

This form efficiency is the least vigorous form employs the adjusted subset of public information, that is, historical information about the share prices itself. New information must by definition be unrelated to the previous information, if not it would not be called new.

Therefore, it follows that every movement in the share price in response to the new information cannot be predicted from last movement or price. The future price cannot be predicted from the last movement of price. The future price cannot be predicted from the historical records and thus the market held that;

No excess returns can be earned by using investment strategies base on historical share prices or other financial data; technical analysis will not be able to produce returns; and one can employ statistical investigations in time series data of prices. The current prices share prices are deem the best, unbiased estimate of the value of the security. Generally, news is assumed to occur randomly so the changes in share prices must also be random.

\subsection{The behavioural finance}

In the standard finance dictum people are deemed to be rational and normal in behavioural finance Thus rational people care about utilitarian characteristics but not value expressive ones and are never confused by cognitive errors, have perfect self control and above all always averse risks and never averse to regret, but normal people do not obediently follow that pattern. Statman (1999) view behavioral finance as an area of study that analyzes the impact of symmetric psychological bias on the decision making process of investors. The proponents of behavioural finance believe that investors are influenced by their emotion in addition to the mean, variance and covariance of assets returns in making investment choices.

This implies that investors will not arrive at the same optimal risky portfolio as suggested by the separation theorem of Tobin (1958). Base on this analogy, it can be argue that the propose asset allocation decision of modern portfolio theory is essentially a suggestion for the market is efficient scenario. The study of behavioral finance serves to provide alternative scenarios for investors as regard to irrational market. The riskreturn pricing relationship as shown by capital asset pricing model would be biased and the portfolios constructed base on the relationship would cease to be mean-variance efficient. The development of behavioral 
finance stems from Kahneman and Tversky (1979) the proponent of prospect theory and a critique of expected theory.

\subsection{The prospect theory}

The underlying principle of prospect theory lies on investor's reaction to risk exposure and display several pervasive effects which are incongruence with the basic fundamentals of expected utility theory and in contrast to expected utility theory. Prospect theory studies the decisions of investors in the presence of uncertainty base on cognitive psychology rather than investor rationality. The expected utility theory posited that investors are risk averse in making investment decisions. In addition to the recognition of risk aversion, prospect theory introduces the concept of loss aversion, which states that investors prefer to avoid losses than to acquire gains. In demonstrating the concept of loss aversion, prospect theory suggests that investors judge the gains and losses of an investment relative to a specific reference point such as the purchase price of an asset. The utility derived from an investment can be express in wave sign form which displays the points where positive utility is derived from gains and negative utility is derived from losses in line with the expected utility theory also call the marginal utility function. The concave shape of curve show the gains, that is, the marginal utility derived from additional gains is increased at a decreasing rate. However, prospect theory also implies diminishing marginal disutility for losses since the function becomes convex when the asset position is below the reference point and the gradient is higher for losses than as obtain for gain.

The implication is on the extent of disutility derived from making losses is larger than the level of utility derived from an equal amount of gains. The theory state that investors due overreact to private information perceive and may under react to publicly available information signal as result of over confidence as perceive precision of private information and the attributed bias causes asymmetric shifts in the confidence of the investors . Possible consequences of biased self-attribution include stock market short-term momentum, short-term earnings drift and long-term reversals from the drift.

On the whole, Mayowa and Richard (2012) are of the opinion that Nigerian stock exchange exhibits weak form as successive price changes are independent and random contend that the market is efficient in the weak form since the successive price changes of the traded securities are independent and random. This denotes that the market is carrying out its key role functions optimally. Also, Sule and Momoh (2009) and Ekeocha (2008) observe that the earning in respect of trading from the Nigerian stock exchange impact positively on the per capita income average Nigerian and most of the variables show positive relationship to foreign direct investment portfolio. Hence market stands to gain from inflow of foreign direct investment on the long run.

Moreover, (Augusting and Nwanneka, 2012) view recent economic down trends exerts adverse effect on the nation's capital market and suggested the adoption of strategic management to facilitate efficiency, effective regulation and stable micro economic environment. The anomalies that nearly led to the total collapse on the Nigerian stock exchange in 2011 called for an inquest into the issues of asymmetric information, insider dealings and policies inconsistencies that characterize the market scenario. Somnath et al, (2008) observed that the value of the market transaction increases from growth, boom and to bust period. Investor's psychology and behaviour impact positively on the market and that negative returns do not affect the volume of trading and above all, investors do not behave in the way of rational behaviour model suggests that their behavour are modified by fads and market bubbles.

\section{Summery and Conclusion}

Researches on capital market as it relate to its economic growth and development functions had being conducted several time to attest and confirm the efficacy of capital market in the economic development of a nation based on the traditional efficient market hypothesis. Burton (2003) opine that prices are unpredictable and random, and there is fair game play among the participants; and Atoyebi et al (2013) maintain that capital market have a strong positive relationship with economic growth. However, the Nigerian capital market maintain a weak form of efficiency resulting to investor's lose of 17 per cent of their holdings in 2011 due to spillover effects of the recent financial crisis and political turmoil in Middle east and North Africa (Onyebuchi, 2012) (al, 2008) (zakari, 1990). According to Augustine and Nwanneka (2012) the poor market performances was sequential to spillover effects from last global economic crisis and of the opinion that adoption of strategic management has become inevitable, and effective regulation will go a long way to forestall micro economic stability, but Somnath et al (2003) are of the opinion that the variation of market growth from boom to burst are the consequences of the investors' psychology and behavioural characteristics. These therefore call for behavioural finance in the scheme of capital market performance analysis.

Kathleen (2012) contends that investors share heuristics contrary to efficient market hypothesis. It is quite obvious that traditional efficient market hypothesis no longer hold sway in the contemporary economic activities. Jay (2003); Somnath et al (2008), Nicola and Marcos (2009) view behavioural finance as an approach for studying finance and economy on the platform of cognitive science and decision making models since 
orthodox economic theories fails to present the decision process of individual in a realistic way on the non rational aspect of their behaviour. It is pertinent that the Nigerian's capital market which was purported to be efficient in a weak form (Mayowa and Richard, 2012) had shown a developmental trap occasioned by the prevalent of insider dealings, asymmetric information and other attendant anomalies. Hence, Zakari (1990), and Burton (2003); observed that behavioural finance explores the main cognitive distortion that could lead to sub optimal decisions like bias, heuristic and framing effects. Olatundun and Ademola (2008) contend that financial factors have insignificant influence in the investment behaviour of Nigerian Firms noting that asymmetric information, agency problems and the market size served as the main determinant of the credit worthiness of the firms, taking into consideration the macro economic conditions. Also, Dimitris and Eftymios (2004) affirm that financial market impact positively on economic growth and that there exist a strong correlation between financial development and output growth, though depending on the focus of the financial system of a country; financial market tends to follow output growth as empirical studies shows positive effect of financial market on economic growth even after taken into consideration the likely bias due to accounting errors resulting from omission of variables and unobserved country variables' specific effects as it may affect economic growth.

Godwin (2010) observed that the Nigerian stock exchange's total market capitalization had been growing relative to the gross national product, also the share price behavioural pattern were in the form random walk as obtain with the random walk theory, of course on the weak form of efficiency. Halit (2003) observe that liberalization of trade do not have simple straight relationship with real growth and most of the empirical research proved that open economy grow faster than close one. In the context of Nigeria however, the removal of the fundamental elements of financial repression that clog the capital inflows has help in boosting the local and foreign investors' confidence. Moreover, Sijing (2006) draws attention to the fundamental and institutional factors which could lead to market imperfection; such as asymmetric information, moral hazard, advance selection, agency and behavioural factors. Stephen (1982) observed that modern market theory depend heavily on the assumptions that investors know the expected risks and returns associated with financial assets, but the immerging and frontier economies are affected by loss of investors' confidence due to agency problem, employment of parallel system of business control, tardy accounting records and low quality auditing standard. Good governance and regulatory smack also play significant role in checking the anomalies in the market. Also, Burton (2003) opines that in market where pricing irregularity and predictable pattern of stock returns exist over time cannot be said to be efficient.

Virtually little research had been conducted on inclusion of behavioural finance in the scheme of evaluating market performances especially in Nigeria. The study had highlighted the imperatives of behavioural finance as one of the core factors to be considered in the analysis of capital market performance. Fidelis and Davidson (1997) and Sunday et al (2009) opine that the Nigerian capital market possess the ability as a catalyst to accelerate economic growth and development, though has not significantly does that due to its low capital absorptive power as it lack both dept and breath with few financial instruments been traded and the method of price regulation do not equally help issues. Onybuchi (2012) point out that in 2011, the investors loss $17 \%$ of their holdings over the 202 companies' equity trading as a result of interactive factors of indigenization of the banks, political crisis in the middle East and North Africa, Euro zone debt crises which culminated into down side risks that dampen the investors' sentiments. The ensued melee lead to all sort of shady dealings and vagrant compromise of the standing, rules and regulations resulting into aligning of about 206 individuals, listed companies and stock brokerage firms to court for one offences or the other. At this juncture, Tokumbo (2011) also attest to it that the Nigerian's capital Market inability to accelerate its economic growth function was due to existence of structural rigidities that characterize the economic policies. The research therefore highlight and advocated the inclusion of the behavioural factors in the anal of capital market performance analysis and take in-depth look on to how it affect investor's investment decision making process and feedback instead of using only statistical data. After all, man is not mathematical, he is psychological.

\section{Reference}

[1]. Adamu t al. (1990). Issues in Privatization and Capital Market Develompmet. Conference of Capital Market Development and Privatization, (pp. 14-16). Bombay.

[2]. Atoyebi. (2013). Capital market and Economic Growth in Nigeria an Emperical Analysis. Journal of social science , 66-68.

[3]. Augusting, N. \&. (2012). Adoption of Strategic Management Approach in the Capital Development: The Nigerian Case. International Journal of Economic and Finance , 223.

[4]. Azeez, O. a. (2012). A Test of Strong Form of Efficiency of the Nigerian Capital Market. Business system review , Vol. 1, Issue 1.

[5]. Bank, W. (2007). Global Financial Crisis. US: World Bank Reports.

[6]. Bayero. (1996). Benefits of capital Market to Indegnious enterprises in nigeria. Security Market Journal, Special edition , 1-86.

[7]. Brtion. (2003)

[8]. Burton. (2003). "The Efficient Market Hypothesis and Its Critics".

[9]. Chuke, N. E. (2012). The Crash of the Nigerian Stock Market: What went wrong, the Consequences and the pancea. Developing Country Study, 105-117.

[10]. Dimitris, E. \&. (2004). Financial Development and Economic Growth: Evidence from Panel Unit Rootand Co Integration. Journal of economic development, 55-74. 
[11]. Tokumbo (2011). Does stock market promote economic growth in Nigeria?

[12]. Fama. (1965). The behaviour of Stock price. Journal of Business , 34-49.

[13]. Fidelis, D. a. (1997). Mobilization of domestic resource forEconomic Development in Nigeria: the Role of the capital market. African Research Consortium (p. Research Paper 56). Kenya: Regal Press Ltd.

[14]. Fisher, J. a. (2005). Security Analysis and Portfolio Management. Delhi: Pearson Education.

[15]. Gill. (1989). Privatization opprotunity for Capital Market development. IMF Series. Abu Dhabi.

[16]. Glenn, B. (2009). Capital Market Integration: A Review of the issues and an assessment of New Zealaand's Position. Canterbury: Ministry of economic develoment and capital market task force.

[17]. Godwin. (2010). Stock Market Prices and Random Walk Hypothesis: Firther Evidences from Nigeria. Journa of economic and International Finance, 49-57.

[18]. Gorge. (2002). Behavioural Microeconomic and Macroeconomic behaviour. The American economic review , 411 - 433.

[19]. Greenwood, J. a. (1990). Financial development, and Economic development and Cultural change. Journal of Economic Dynamic and Control , 257-268.

[20]. Ishola. (2008). Efficient Market hypothesis and Behavioral Finace:Review of Literatuer. European Journal Of Social Science. , 111.

[21]. Jay. (2003). Behavioural Finance. Pacific basin Finance, 429 - 437.

[22]. Jensen. (1978). Some Annomalies Evidence Regarding Market Efficiency. Journal of Financial Economy , 304-405.

[23]. Joseph. (2000). Capital Market Liberazition, Economic Growth, and Instabilty. World bank Development , 1075-1086.

[24]. Joseph(1997). Modern managemet Technique and Developmet Admnistration. Onitsha, Nigeria: Abbot communication.

[25]. Kahnemann, T. a. (1979). An Analysis of decision under Risk. Econometrica, 263-291.

[26]. kathleen. (2012). capital market Theories: market efficiency versus investor prospect. international Journal of business and Economic research, vol. 11, No. 8.

[27]. kathleen. (2012). Capital Market Theories: Market Efficiency versus Investor Prospects. journal Of Business and economic Research , 8-11.

[28]. Levine. (1991). Stock Market Growth and Tax policy. Journal of Economic Literature , 1445-1465

[29]. Maku, A. a. (2010). determinant of Stock Market Performance in Nigeria: Long - Run Analysis. Journal of Management and Organizational Behaviour

[30]. Malkiel. (2003). The Efficient Market Hypothesis and Its Critics. Journal of Economic Perspectives , 58-82.

[31]. Marcos, N. a. (2009). Modeling Cognitive Distortion of Behavioural finance . IEEE Computer society , 204 - 209.

[32]. Mayowa, A. A. (2012). Testing the Weak form of Market Efficiency in Nigerian Capital Market. Accounting and Finance Reearch , 169 .

[33]. Michael. (2010). Investor,s Sentiment, Stock Market Liquidity and Economic Growth in Nigeria. Journal of Social Science , 63-69.

[34]. Nwannneka, A. \&. (2012). adoption of Strategic management Approach in the Capital Market Development. International Journal of Economic and Finance, 233.

[35]. Okafo. (1987). Ivestiment Decision: An Evaluation of Projects and Securities. London: Cassell LTD.

[36]. Okay. (2012). Stock Market development and Economic Growth in Nigeria: Market size versus Liquidity. canadian social science , $65-70$.

[37]. oke, A. a. (2012). Impact of Capital Market Reform on Economic Growth: The nigerian Experience. Australian Journal of Business and management , 20-30.

[38]. Olatundun, A. a. (2008). Capital Market imperfection and Corporate Investment Behaviour: A switching Regression Approach using Panel data for Nigeria manufacturing Firms. Journal of Investment and banking. Eurojournal Publication

[39]. Onyebuchi. (2012). The Nigerian stock market in 2012: Strong foundametals clouded by uncertainties. Modern ghana news , http://www.modernghana.com.

[40]. Ozoemena, O. a. (2008). The stock Market cannel of Monetary policy Transmission in Nigeria. CBN Economic Review , 29.

[41]. Pagano. (1993). Financial Market and Growth: An Overview. European Economic Review, 613-622.

[42]. Paniscos., P. a. (2001). Financial development and Economic Growth: The Role of Capital Market. Journal of Money, Credit and Banking. , 16-41.

[43]. Philip. (1985). The Role of Nigerian Capital Market in a receased economy. The CBN Bullion , 21-29.

[44]. Roll. (1978). Ambiguity when Perormance is Measuered by the Security market Line. Journal of Finance, 1051-1069.

[45]. Samuel, W. a. (1981). Management of Company Finance. London: Thomas Nelson Smith G Investment.

[46]. Singh. (1997). Financial Libralization, Stock market and Economic Development. Economic Journal , 771-781.

[47]. Solomon. (2007). The Capital Market allocation and Monitoring Role of capital Market: Theory and International Evidence. Journal of finance and Quantitative Analysis , 36-42.

[48]. Somnath et al (2008). a comprenhensive study of behavioural finance. Journal of financial professionals, www.financialpro.com

[49]. Statman. (1999). Behavioural Finance, Past Battles and Future Engagements. inancial Analyst Journal , 18-27.

[50]. Stean. (2004). The efficient Market hypothesis and its Validity in Today's Market. London: Grin Publish and Find Knowledge.

[51]. Stigliz. (1999). Lessson ffrom the global Financial Crisis. Chicago: Reserve Bank of Chicago.

[52]. Sunday et al. (2009). Appraisal of capital market Efficiency on economic Growth in Nigeria. International Journal of Business and Management, 219-228.

[53]. Tobi. (1958). Liquidity Preference as Behaviour toward Risk. The Review of Economic Studies , 65-86.

[54]. Yanikkaya, H. (2003). Trade openness and Economic growth: A Cross Country Emperical Investigation. Journal of development Economica, 57-89.

[55]. zakari. (1990). Stock price behaviour in underdeveloped capital market: Nigerian in Contrast to the US. Journal of Applied Business Research, Vol.6, No 4. 